\title{
Soil Chemical attributes under different management systems in Cerrado-Amazon
}

\section{ecotone}

Atributos químicos do solo sob diferentes sistemas de manejo no ecótono Cerrado-Amazônia

Atributos químicos del suelo bajo diferentes sistemas de gestión en el ecotono Cerrado-Amazonas

Received: 05/13/2021 | Reviewed: 05/22/2021 | Accept: 06/11/2021 | Published: 06/24/2021

\author{
Amanda da Silva Reis \\ ORCID: https://orcid.org/0000-0001-8577-669X \\ Universidade Federal do Tocantins, Brazil \\ E-mail: areis176@gmail.com \\ Rubson da Costa Leite \\ ORCID: https://orcid.org/0000-0002-3572-7600 \\ Universidade Federal Rural da Amazônia, Brazil \\ E-mail: rubsonif@gmail.com \\ Guilherme Octávio de Sousa Soares \\ ORCID: https://orcid.org/0000-0001-8414-8958 \\ Universidade Federal do Tocantins, Brazil \\ E-mail: guilhermeoctavio21@hotmail.com \\ José Lucas de Sousa Soares \\ ORCID: https://orcid.org/0000-0003-3983-1031 \\ Instituto Federal do Tocantins, Brazil \\ E-mail: joselucassoares13@gmail.com \\ Flavia Barreira Gonçalves \\ ORCID: https://orcid.org/0000-0001-8624-8637 \\ Universidade Federal do Tocantins, Brazil \\ E-mail: flaviabarreira@ hotmail.com \\ Rodrigo Ribeiro Fidelis \\ ORCID: https://orcid.org/0000-0002-7306-2662 \\ Universidade Federal do Tocantins, Brazil \\ E-mail: fidelisrr@uft.edu.br \\ Antônio Clementino dos Santos \\ ORCID: https://orcid.org/0000-0001-7943-7923 \\ Universidade Federal do Tocantins, Brazil \\ E-mail: clementino@mail.uft.edu.br
}

\begin{abstract}
The Cerrado-Amazonas ecotone occupies $4.85 \%$ of the Brazilian territory, with almost $60 \%$ of its area deforested. Inadequate soil management practices cause changes in the physical, chemical and biological soil attributes. This study aimed to characterize soil chemistry in different management systems, identifying its efficiency. Ten areas were divided into two soil classes (Ultisol and Entisol quartzipsamment), each comprising a management system (1 silvopastoral with 30\% shade (SP30), 2 - silvopastoral with 60\% shade (SP60), 3 - secondary forest, 4 - native forest, 5 - pasture conventional (CP)). The samples were collected at depths of 0-10, 10-20 and 20-40 cm. The chemical attributes of the soil analyzed were $\mathrm{pH}, \mathrm{P}, \mathrm{K}+, \mathrm{Ca}^{2+}, \mathrm{Mg}^{2+}, \mathrm{H}+\mathrm{Al}^{3+}, \mathrm{Al}^{3+}$, sum of bases ( $\mathrm{SB}$ ), effective cation exchange capacity (CEC), CEC at $\mathrm{pH} 7$, saturation base (V\%) and aluminum saturation $(\mathrm{m} \%)$. The data were submitted to principal component analysis and analysis of variance and Tukey's test $(\mathrm{p}<0.05)$. There were minor changes in the attributes analyzed in the Entisol management systems, comparing the other systems with the reference system (native forest); however, SP30 was more suitable, as it increased the $\mathrm{pH}$ and the values of essential cations in the soil. In Ultisol, the SP60 and CP systems showed higher averages in the studied attributes, it is inferred that these systems have similar efficiency in land use, positioning them as the best systems studied in this soil class.
\end{abstract}

Keywords: Entisol; Ultisol; Silvopastoral; Brazilian soils.

\section{Resumo}

O ecótono Cerrado-Amazonas ocupa $4,85 \%$ do território brasileiro, sendo quase $60 \%$ de sua área desmatada. As práticas inadequadas de manejo do solo ocasionam mudanças nos atributos físicos, químicos e biológicos do solo. Este estudo objetivou caracterizar a química do solo em diferentes sistemas de manejo, identificando sua eficiência. Foram avaliadas dez áreas divididas em duas classes de solo (Argissolo e Neossolo quartzarênico), cada uma compreendendo um sistema de manejo (1 - silvipastoril com 30\% de sombra (SP30), 2 - silvipastoril com 60\% de sombra (SP60), 3 - floresta secundária, 4 - floresta nativa, 5 - pastagem convencional (PC). As amostras foram coletadas em profundidades de 0- 
10, 10-20 e 20-40 cm. Os atributos químicos do solo analisados foram $\mathrm{pH}, \mathrm{P}, \mathrm{K}+, \mathrm{Ca}^{2+}, \mathrm{Mg}^{2+}, \mathrm{H}^{+} \mathrm{Al}^{3+}, \mathrm{Al}^{3+}, \mathrm{soma}^{2}$ de bases (SB), capacidade efetiva de troca catiônica (CTC), CEC em pH 7, saturação por base (V\%) e saturação por alumínio $(\mathrm{m} \%)$. Os dados foram submetidos à análise de componentes principais e à análise de variância e teste de Tukey ( $\mathrm{p}<0,05)$. Houve pequenas alterações dos atributos analisados nos sistemas de manejo do Neossolo, comparandose os demais sistemas com o sistema de referência (mata nativa); no entanto, o SP30 foi mais adequado, pois aumentou o pH e os valores de cátions essenciais do solo. No Argissolo os sistemas SP60 e PC apresentaram médias superiores nos atributos estudados, infere-se que esses sistemas apresentam eficiência semelhante no uso do solo, posicionando-os como os melhores sistemas estudados nesta classe de solo.

Palavras-chave: Neossolo; Argissolo; Silvopastoral; Solos brasileiros.

\section{Resumen}

El ecotono Cerrado-Amazonas ocupa el 4,85\% del territorio brasileño, con casi el $60 \%$ de su superficie deforestada. Las prácticas inadecuadas de manejo del suelo provocan cambios en los atributos físicos, químicos y biológicos del suelo. Este estudio tuvo como objetivo caracterizar la química del suelo en diferentes sistemas de manejo, identificando su eficiencia. Diez áreas se dividieron en dos clases de suelo (Ultisol and Entisol quartzipsamment), cada una con un sistema de manejo (1 - silvopastoril con 30\% de sombra (SP30), 2 - silvopastoril con 60\% de sombra (SP60), 3 - bosque secundario, 4 - bosque nativo, 5 - pastizal convencional (CP)). Las muestras se recolectaron a profundidades de 0-10, 10-20 y 20-40 cm. Los atributos químicos del suelo analizados fueron $\mathrm{pH}, \mathrm{P}, \mathrm{K}^{+}, \mathrm{Ca}^{2+}, \mathrm{Mg}^{2+}, \mathrm{H}^{2} \mathrm{Al}^{3+}, \mathrm{Al}^{3+}, \mathrm{suma} \mathrm{de}^{-}$ bases (SB), capacidad de intercambio catiónico efectivo (CEC), CEC a pH 7, saturación base (V\%) y saturación de aluminio $(\mathrm{m} \%)$. Los datos fueron sometidos a análisis de componentes principales y análisis de varianza y prueba de Tukey ( $\mathrm{p}$ <.05). Hubo pequeños cambios en los atributos analizados en los sistemas de manejo Entisol, comparando los otros sistemas con el sistema de referencia (bosque nativo); sin embargo, SP30 fue más adecuado, ya que aumentó el pH y los valores de cationes esenciales en el suelo. En Ultisol, los sistemas SP60 y CP mostraron promedios más altos en los atributos estudiados, se infiere que estos sistemas tienen similar eficiencia en el uso del suelo, posicionándolos como los mejores sistemas estudiados en esta clase de suelos.

Palabras clave: Entisol, Ultisol, Silvopastoral, Suelos brasileños.

\section{Introduction}

The Cerrado-Amazon ecotone occupies $4.85 \%$ of the Brazilian territory with almost $60 \%$ of its area deforested (MMA, 2003). Ecological zones have been converted into agricultural landscapes, especially in pastures (Araújo et al., 2009), which are generally handled inappropriately, resulting in the degradation of pastures and soil attributes. In pastures, intensive and indiscriminate use causes adverse changes in the chemical, physical and biological attributes of the soil (Rocha Junior, Silva \& Guimarães, 2013).

In Entisol quartzipsamment the use of native pasture, agriculture-livestock integration, cultivated pasture, soybean and corn under no-tillage, do not provide significant changes in $\mathrm{pH}$ values, but erosion and leaching present in this soil cause potassium loss $\mathrm{K}^{+}$and $\mathrm{Ca}+\mathrm{Mg}$ and consequent soil degradation (Carneiro et al., 2009; Oliveira et al., 2017). The Entisol Quartzipsamment in the Cerrado region have low natural fertility and the variation in the chemical attributes of the soil is mainly related to the management of fertilization (Oliveira., 2017)

In order to delay the soil degradation process or to recover what is already degraded, systems of use and management have been sought, which integrate annual crops, forests, with the presence of animals (Bono, Macedo \& Tormenta, 2013). Alternatives for recovery and reintroduction of these areas to the productive process include reopening, soil correction and fertilization, and/or agroforestry activities. Therefore, increasing biodiversity and sustainability of pasture ecosystems can be achieved by introducing or maintaining trees, composing agroforestry systems that may be alternatives for reincorporating areas into the productive system (Godinho et al., 2014).

In silvopastoral systems the accumulation and decomposition of litter are influenced by the management system. However, these events can occur with greater intensity than those existing in pasture areas under monoculture and even in native forest. Studies have observed that the recycling of base cations $\left(\mathrm{Ca}^{2+}, \mathrm{K}^{+}, \mathrm{Mg}^{2+}\right.$, and $\left.\mathrm{Na}^{+}\right), \mathrm{N}$ and $\mathrm{P}$ under integrated systems was superior $(41,116,64,21,19$, and 55\%, respectively) to pasture systems under monoculture (Wall, 2006; Bahamonde et al., 2012). 
The dynamics of accumulation, decomposition and release of nutrients is conditioned to the adopted silvopastoral system model, such as level of shading, number and type of trees (Benavides, Douglas \& Osoro, 2009), forage species, presence of animals and chemical, physical and chemical factors (Mancilla-Leytón, Sánchez-Lineros \& Vicente, 2013) from the litter itself and the environment.

Considering that in general tropical soils have low natural fertility, organic matter provides significant contribution from the release of its nutrients as a source of energy for organisms and plants (Cordeiro et al., 2010). The organic content of the soil can improve the stability of the aggregates and is relevant for the chemical attributes in tropical soils.

Thus, this study aimed to define soil chemical quality in different management systems in order to identify their efficiency.

\section{Methodology}

\subsection{Experimental conditions}

The study was conducted in a Cerrado-Amazonian ecotone area in Araguaína, Tocantins state, Brazil. The climate of the region is classified as Aw (hot and humid) (Dubreuil et al., 2018), with well-defined seasons, average annual precipitation of $1700 \mathrm{~mm}$, and average temperature of $26^{\circ} \mathrm{C}$. The experiment was developed in two different soil classes, classified according to the Brazilian Soil Classification System (Santos et al., 2018). The first soil was classified as Ultisol (Bockheim et al., 2014), located at coordinates UTM: zone 22, N 810489.34, E 9213706.86, and the second one was classified as Entisol QuartziQuartzipsamment (Bockheim et al., 2014), located at coordinates UTM: zone 22, N 808635.00, E 9214729.00.

\subsection{Experimental Design and data collection}

Five management systems were studied: 1 - silvopastoral with 30\% shading, 2 - silvopastoral with $60 \%$ shading, 3 secondary forest, 4 - native forest, 5 - pasture with conventional management.

The areas of Entisol QuartziQuartzipsamment s had the following history of use: the silvopastoral areas, originating from the association of Mombasa grass (Megathyrsus maximum cv Mombasa) and thinned native vegetation ("Fava de bolota" Parkia Platycephala, "Pimenta de macaco"- Xylopia Aromática, "Jatobá do cerrado" Hymenea Stignocarpa, "Embaúba" Cecropia Pachytachya), were managed the first time in October 2009, using a luxmeter so that the first area of silvopasture had $30 \%$ shading and the second $60 \%$ shading. The secondary forest is an abandoned pasture area without treatment. The pasture composed of Mombasa grass with conventional management system has been used since 2008 with treatments such as liming and frequent fertilization.

Areas of Ultisol had the following history of use: the silvopastoral systems, which were established in a forest environment of Babassu (Attalea speciosa) intercropped with Mombasa grass, in November 2011, by the thinning of the original vegetation, determining the shading levels of $30 \%$ and $60 \%$. The secondary forest comprised an abandoned pasture in agricultural degradation, with no treatment. The native forest has the predominance of Babassu trees. The pasture area with conventional management has been used since 2011, corrected and fertilized. The first three areas were managed in 2011 with dolomitic limestone $\left(1 \mathrm{tha}^{-1}\right), 100 \mathrm{~kg}$ of $\mathrm{P}_{2} \mathrm{O}_{5}$ (Single Super Phosphate) and $120 \mathrm{~kg}$ of $\mathrm{K}_{2} \mathrm{O}(\mathrm{KCl})$, which were distributed in the total area in a single application.

Soil sampling was carried out in each management system, where 8 samples composed of 8 subsamples were collected. The depths of the samples were 0-10 cm, 10-20 cm, and 20-40 cm. Samples were conditioned in plastic bags and analyzed for $\mathrm{pH}$ in $\mathrm{CaCl}_{2}$, available phosphorus $(\mathrm{P})$ and exchangeable potassium $(\mathrm{K})$, extracted using the Mehlich-1 solution. Contents of 
calcium, magnesium and exchangeable aluminum were extracted in $1 \mathrm{~mol} \mathrm{~L}^{-1} \mathrm{KCl}$. Potential acidity $\left(\mathrm{H}+\mathrm{Al}^{3+}\right)$ was extracted in $0.5 \mathrm{~mol} \mathrm{~L}^{-1}$ calcium acetate at $\mathrm{pH}$ 7.1-7.2. The sum of bases (S), base saturation (V\%), aluminum saturation (m \%), effective $\mathrm{CEC}(\mathrm{T})$ and $\mathrm{CEC}$ at $\mathrm{pH} 7(\mathrm{t})$ were determined.

\subsection{Statistical Analysis}

Statistical analysis was carried out. Initially the data were submitted to principal component analysis (PCA) in order to establish which attributes analyzed had greater contribution to the component to simplify the structure of the set of analyzed variables. The correlation data transformation matrix was used, since the values are not in the same unit of measurement and scales. The most relevant attributes identified from the PCA were submitted to analysis of variance and the Tukey test for comparison of means at a probability level of 0,05 .

\section{Results and Discussion}

By the Principal Component Analysis, it was possible to obtain the graphical representation and eigenvalues of the variables (Tables 1, 2 and 3), thus synthesizing the most influential characteristics and variations of soil attributes in the studied areas.

The analysis shows in the tables, that the first two main components made it possible to explain $70 \%$ or more of the variance contained in the original variables at all depths. The first main component is the most important, as it corresponds to the direction of greatest variance in the multivariate space (Lyra et al., 2010). Such a statement could be confirmed in the correlation circles (Figure 1 (a), (b), (c)) where the data demonstrated that component 1 was responsible for 63.56, 61.70 and $58.34 \%$ of the variation of the first component, at the depths of 0-10, 10-20 and 20-40 cm, respectively.

Tables 1, 2 and 3- Correlation of soil chemical attributes with the main components (CP) of soil chemical attributes at depths of 0-10 cm (Table 1), 10-20 cm (Table 2), 20-40 cm (Table 3).

\begin{tabular}{|c|c|c|c|c|c|c|c|c|}
\hline \multicolumn{3}{|c|}{ Table 1} & \multicolumn{3}{|c|}{ Table 2} & \multicolumn{3}{|c|}{ Table 3} \\
\hline Attribute & CP1 & $\mathrm{CP} 2$ & Attribute & $\mathrm{CP} 1$ & $\mathrm{CP} 2$ & Attribute & CP1 & $\mathrm{CP} 2$ \\
\hline MO & $-0,82$ & $-0,21$ & MO & $-0,68$ & 0,05 & $\mathrm{pH}$ & $-0,90$ & $-0,06$ \\
\hline $\mathrm{pH}$ & $-0,95$ & $-0,14$ & $\mathrm{pH}$ & $-0,95$ & 0,04 & $\mathrm{Ca}$ & $-0,90$ & $-0,13$ \\
\hline $\mathrm{Ca}$ & $-0,87$ & 0,35 & $\mathrm{Ca}$ & $-0,87$ & $-0,24$ & $\mathrm{Mg}$ & $-0,92$ & $-0,12$ \\
\hline $\mathrm{Mg}$ & $-0,88$ & 0,26 & $\mathrm{Mg}$ & $-0,90$ & $-0,11$ & $\mathrm{Al}$ & 0,21 & $-0,81$ \\
\hline $\mathrm{Al}$ & 0,57 & 0,40 & $\mathrm{Al}$ & 0,58 & $-0,58$ & $\mathrm{P}$ & 0,22 & 0,50 \\
\hline $\mathrm{P}$ & $-0,03$ & $-0,79$ & $\mathrm{P}$ & 0,19 & 0,70 & $\mathrm{~K}$ & $-0,74$ & 0,05 \\
\hline $\mathrm{K}$ & $-0,87$ & 0,01 & K & $-0,84$ & $-0,03$ & $\mathrm{H}+\mathrm{Al}$ & 0,48 & $-0,61$ \\
\hline $\mathrm{H}+\mathrm{Al}$ & 0,73 & 0,20 & $\mathrm{H}+\mathrm{Al}$ & 0,58 & $-0,26$ & $\mathrm{~m}$ & 0,85 & $-0,24$ \\
\hline $\mathrm{m}$ & 0,81 & 0,23 & $\mathrm{~m}$ & 0,86 & $-0,30$ & V & $-0,98$ & $-0,08$ \\
\hline V & $-0,98$ & 0,10 & V & $-0,98$ & $-0,10$ & CEC & $-0,91$ & $-0,26$ \\
\hline CEC & $-0,82$ & 0,45 & CEC & $-0,87$ & $-0,29$ & & & \\
\hline EC & $-0,79$ & $-0,16$ & & & & & & \\
\hline
\end{tabular}

Fonte: Authors.

Component 2 represented only 11.48, 10.51, and $14.46 \%$ of the variation, respectively. Together, the two factors comprised more than $70 \%$ of the variation of the data in each analyzed depth. Thus, it was not necessary to add any factor because when this percentage is reached, the representativeness of the total variation of the data is guaranteed (Rencher, 2002). When studying physical and chemical attributes Loss et al. (2009) and Alves et al. (2014), found values of variance above 70\%, these 
values were linked to the variability of these attributes.

In the 0-10 depth, the attributes $\mathrm{V} \%, \mathrm{pH}, \mathrm{Ca}^{2+}, \mathrm{Mg}^{2+}, \mathrm{K}^{+}$, and $\mathrm{CEC}$ had a significant contribution in the formation of the first component, positively correlating with each other, and negatively with $\mathrm{Al}^{3+}$ and $\mathrm{m} \%$, which also contributed to the factor.

At the depths 10-20 and 20-40 cm (fig. 1- $\mathrm{b}$ and c), the attributes $\mathrm{pH}, \mathrm{Ca}^{2+}, \mathrm{Mg}^{2+}, \mathrm{K}^{+}, \mathrm{CEC}$, and $\mathrm{V} \%$ were positively correlated; and $\mathrm{m} \%$ negatively correlated, which also contributed to the first component. The positive correlation of V \% with both variables is easily understood, since the $\mathrm{V} \%$ value is the percentage of cation exchange points that are occupied by bases. It can also be seen as a response related to soil acidity.

The variables $\mathrm{Al}^{3+}$ and $\mathrm{m} \%$ are negatively related to the others, indicating that the effect of the variation factor provided the decrease of their values and increase of others (Guedes et al., 2006). The positive correlation between the attributes $\mathrm{Al}^{3+}$ and $\mathrm{m} \%$ is expected, since $\mathrm{m} \%$ expresses the quantity of the effective CEC that is occupied by exchangeable $\mathrm{Al}^{3+}$ ions.

The second component represented only $11.48,10.51$ and $14.46 \%$ of the total data variation, at depths of $0-10,10-20$, 20-40 cm, respectively, where $\mathrm{P}$ was the attribute that presented a considerable contribution to the formation of this factor at depths of 0-10 and 10-20 cm, which was already expected, since the soil was managed with phosphate fertilization in 2014. It was applied $60 \mathrm{~kg} \mathrm{ha}^{-1}$ year ${ }^{-1}$ of $\mathrm{P}_{2} \mathrm{O}_{5}$, distributed in a single application in the silvopasture system of $30 \%$ shading in the Ultisol, and $50 \mathrm{~kg} \mathrm{ha}^{-1}$ year- ${ }^{-1}$ of $\mathrm{P}_{2} \mathrm{O}_{5}$ in the pasture area of the Entisol quartzipsamment, while in the depth of $20-40 \mathrm{~cm}, \mathrm{Al}^{3+}$ was the only variable to have a significant contribution in the formation of the component. 
Research, Society and Development, v. 10, n. 7, e36210716045, 2021

(CC BY 4.0) | ISSN 2525-3409 | DOI: http://dx.doi.org/10.33448/rsd-v10i7.16045

Figure 1. Circle of the correlations of the plane formed by the main components 1 and 2 of the soil chemical attributes at depth 0-10 (a), depth of 10-20 (b), and depth 20-40 cm (c).

(a)

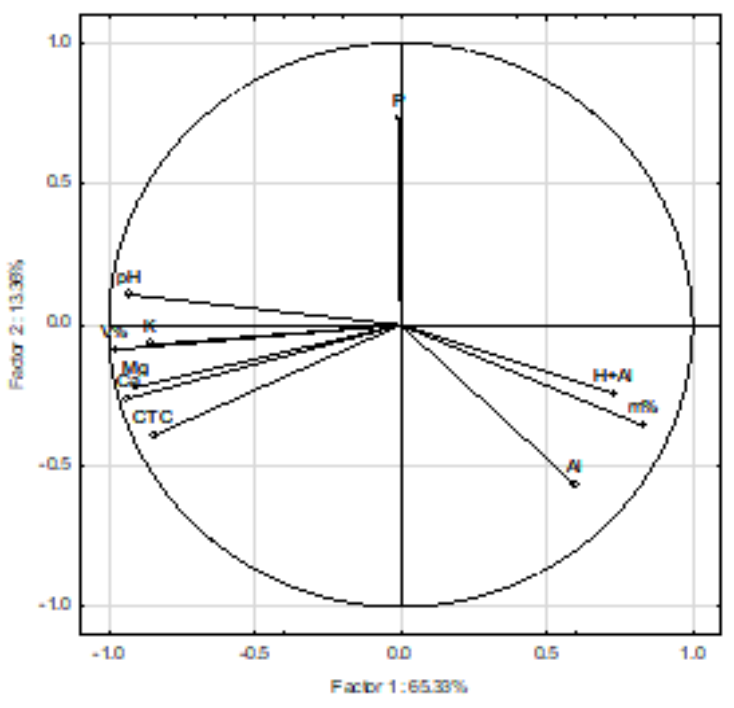

(b)

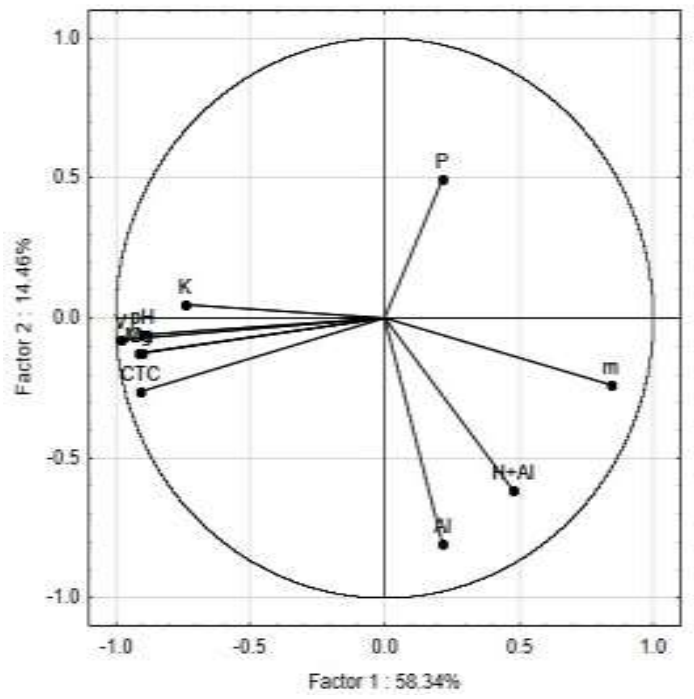

(c)

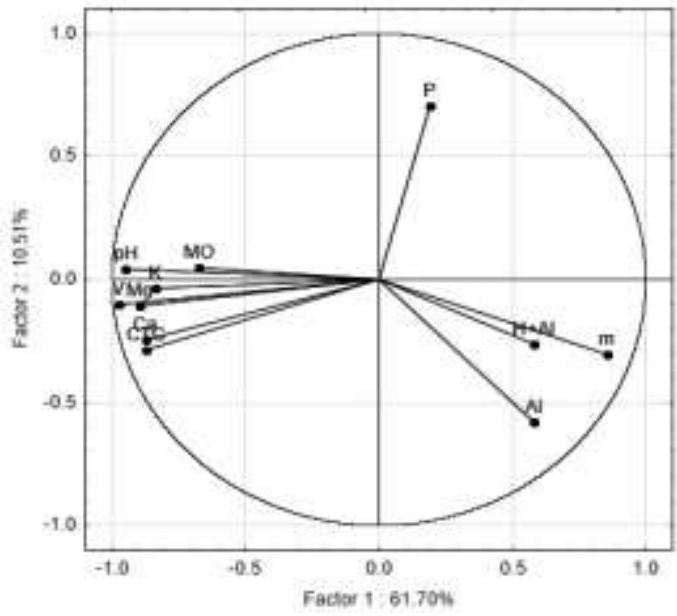

Fonte: Authors.

The $\mathrm{pH}$, potential acidity, aluminum saturation, phosphorus, potassium, calcium, magnesium, cation exchange capacity, and base saturation variables contributed significantly to the components formed for depth of $0-10 \mathrm{~cm}$, which are shown in Table 4. 
Table 4: Soil $\mathrm{pH}$ (in $\left.\mathrm{CaCl}_{2}\right)$, phosphorus $(\mathrm{P})$, potassium $\left(\mathrm{K}^{+}\right)$, calcium $\left(\mathrm{Ca}^{2+}\right)$, magnesium $\left(\mathrm{Mg}^{2+}\right)$, potential acidity $\left(\mathrm{H}+\mathrm{Al}^{3+}\right)$, aluminum saturation (V \%), cation exchange capacity (CTC) of Ultisol and Entisol quartzipsamment, in the depth of 0-10 cm in the different management systems.

\begin{tabular}{|c|c|c|c|c|c|c|c|}
\hline \multirow{2}{*}{ Soil } & \multicolumn{5}{|c|}{ Management system* } & \multirow{2}{*}{ Average } & \multirow{2}{*}{$\begin{array}{l}\mathrm{CV} \\
\%\end{array}$} \\
\hline & 1 & 2 & 3 & 4 & 5 & & \\
\hline \multicolumn{8}{|c|}{$\mathrm{pH}\left(\right.$ in $\left.\mathrm{CaCl}_{2}\right)$} \\
\hline Ultisol & $5.47 \mathrm{Ab}$ & $5.92 \mathrm{aA}$ & $4.95 \mathrm{aC}$ & $4.49 \mathrm{aD}$ & $5.77 \mathrm{aA}$ & 5.32 & \multirow{3}{*}{3.6} \\
\hline Entisol & $3.58 \mathrm{bBC}$ & $3.41 b C D$ & $3.88 \mathrm{bA}$ & $3.23 \mathrm{bD}$ & $3.80 \mathrm{bAB}$ & 3.58 & \\
\hline Average & 4.53 & 4.66 & 4.42 & 3.86 & 4.78 & & \\
\hline \multicolumn{8}{|c|}{$\mathrm{H}+\mathrm{Al}^{3+}\left(\mathrm{cmol}_{\mathrm{c}} \mathrm{dm}^{-3}\right)$} \\
\hline Ultisol & $1.69 \mathrm{bB}$ & $1.93 \mathrm{bB}$ & $2.19 \mathrm{aAB}$ & $2.98 \mathrm{bA}$ & $2.51 \mathrm{bAB}$ & 2.26 & \multirow{2}{*}{19.4} \\
\hline Entisol & $4.34 \mathrm{aB}$ & $6.12 \mathrm{aA}$ & $1.89 \mathrm{aC}$ & $4.71 \mathrm{aB}$ & $4.36 \mathrm{aB}$ & 4.28 & \\
\hline Average & 3.02 & 4.03 & 2.04 & 3.85 & 3.44 & & \\
\hline \multicolumn{8}{|c|}{$\mathrm{P}\left(\mathrm{mg} \mathrm{dm}^{-3}\right)$} \\
\hline Ultisol & $3.22 \mathrm{aA}$ & $3.29 \mathrm{aA}$ & $2.52 \mathrm{aB}$ & $2.57 \mathrm{aB}$ & $2.64 \mathrm{bB}$ & 2.85 & \multirow{2}{*}{13.3} \\
\hline Entisol & $2.72 \mathrm{bB}$ & $2.74 \mathrm{bB}$ & $2.73 \mathrm{aB}$ & $2.61 \mathrm{aB}$ & $3.51 \mathrm{aA}$ & 2.86 & \\
\hline Average & 2.97 & 3.02 & 2.63 & 2.59 & 3.08 & & \\
\hline \multicolumn{8}{|c|}{$\mathrm{K}^{+}\left(\mathrm{cmol}_{\mathrm{c}} \mathrm{dm}^{-3}\right)$} \\
\hline Ultisol & $0.048 \mathrm{aBC}$ & $0.058 \mathrm{aAB}$ & $0.036 \mathrm{aC}$ & $0.048 \mathrm{aBC}$ & $0.0766 \mathrm{aA}$ & 0.053 & \multirow{3}{*}{47.6} \\
\hline Entisol & $0.001 \mathrm{bA}$ & $0.001 \mathrm{bA}$ & $0.003 \mathrm{bA}$ & $0.003 \mathrm{bA}$ & $0.004 \mathrm{bA}$ & 0.002 & \\
\hline Average & 0.025 & 0.03 & 0.02 & 0.03 & 0.04 & & \\
\hline \multicolumn{8}{|c|}{$\mathrm{Ca}^{2+}\left(\mathrm{cmol}_{\mathrm{c}} \mathrm{dm}^{-3}\right)$} \\
\hline Ultisol & $6.67 \mathrm{aCD}$ & $5.62 \mathrm{aD}$ & $9.54 \mathrm{aA}$ & $7.24 \mathrm{aBC}$ & $8.17 \mathrm{aB}$ & 7.45 & \multirow{2}{*}{24.7} \\
\hline Entisol & $0.21 \mathrm{bA}$ & $0.17 \mathrm{bA}$ & $0.082 \mathrm{bA}$ & $0.04 \mathrm{bA}$ & $0.22 \mathrm{bA}$ & 0.14 & \\
\hline Average & 3.44 & 2.89 & 4.81 & 3.64 & 4.2 & & \\
\hline \multicolumn{8}{|c|}{$\mathrm{Mg}^{2+}\left(\mathrm{cmol}_{\mathrm{c}} \mathrm{dm}^{-3}\right)$} \\
\hline Ultisol & $2.70 \mathrm{aB}$ & $2.315 \mathrm{aB}$ & $2.89 \mathrm{aB}$ & $2.21 \mathrm{aB}$ & $4.61 \mathrm{aA}$ & 2.9 & \multirow{3}{*}{42.1} \\
\hline Entisol & $0.25 \mathrm{bA}$ & $0.22 \mathrm{bA}$ & $0.23 \mathrm{bA}$ & $0.06 \mathrm{bA}$ & $0.25 \mathrm{bA}$ & 0.2 & \\
\hline Average & 1.48 & 1.27 & 1.56 & 1.14 & 2.43 & & \\
\hline \multicolumn{8}{|c|}{$\mathrm{V} \%$} \\
\hline Ultisol & 84.74 & 79.07 & 86.85 & 75.18 & 83.63 & $81.90 \mathrm{a}$ & \multirow{2}{*}{11.1} \\
\hline Entisol & 10.17 & 6.13 & 15.85 & 2.27 & 9.86 & $8.86 \mathrm{~b}$ & \\
\hline Average & $47.46 \mathrm{ab}$ & $42.60 \mathrm{bc}$ & $\begin{array}{c}51.35 \mathrm{a} \\
\mathrm{m} \%\end{array}$ & $38,72 \mathrm{c}$ & $46,75 a b$ & & \\
\hline Ultisol & $0.93 \mathrm{aA}$ & $0 \mathrm{aA}$ & $0.18 \mathrm{Aa}$ & $0 \mathrm{aA}$ & $0 \mathrm{aA}$ & 0.48 & \multirow{2}{*}{41.4} \\
\hline Entisol & $12.85 \mathrm{bC}$ & $25.11 \mathrm{bB}$ & $22.59 \mathrm{Bb}$ & $41.27 \mathrm{bA}$ & $22.08 \mathrm{bB}$ & 24.78 & \\
\hline Average & 6.89 & 12.56 & 11.38 & 20.63 & 11.04 & & \\
\hline \multicolumn{8}{|c|}{$\mathrm{CEC}\left(\mathrm{cmol}_{\mathrm{c}} \mathrm{dm}^{-3}\right)$} \\
\hline Ultisol & $11.12 \mathrm{aBC}$ & $9.93 \mathrm{aC}$ & $17.25 \mathrm{Aa}$ & $12.484 \mathrm{aB}$ & $15.38 \mathrm{aA}$ & 13.23 & \multirow{2}{*}{18.2} \\
\hline Entisol & $4.81 \mathrm{bA}$ & $6.51 \mathrm{bA}$ & $2.21 \mathrm{Bb}$ & $4.82 \mathrm{bA}$ & $4.83 \mathrm{bA}$ & 4.63 & \\
\hline Average & 7.96 & 8.21 & 9.72 & 8.65 & 10.11 & & \\
\hline
\end{tabular}

Note. Lowercase letters compare columns. Capital letters compare rows. The averages followed by the same letter did not differ statistically from each other. The Tukey test was applied at $5 \%$ probability level. $* 1$ - silvopasture with $30 \%$ shading, 2 - silvopasture with $60 \%$ shading, 3 - secondary forest, 4 - native forest, 5 - pasture with conventional management. Source: Authors.

Between the two studied soils, there was a difference in $\mathrm{pH}$ and $\mathrm{H}+\mathrm{Al}^{3+}$, whereas the $\mathrm{P}$ variable did not present a significant difference ( $\mathrm{p}>0.01$ ) between the two soils in two of the management systems. It was expected, since the systems in question (3 - secondary forest and 4 - native forest) do not have a history of management of fertilization and, thus, presented similar average values. 
The variables that refer to soil acidity $\left(\mathrm{pH}, \mathrm{H}+\mathrm{Al}^{3+}\right.$, and $\mathrm{m} \%$ ) presented statistical difference between the two analyzed soils. Among the management systems, only systems 1, 2, and 5 in Ultisol presented average $\mathrm{pH}$ values above 5 (5.47, 5.92, 5.77, respectively); the other systems presented mean values that indicate high soil acidity.

In Entisol, low pH values are expected since originally, they already have a mineralogical nature poor in basic cations because they are predominantly composed of quartz (Carvalho et al., 2015). Acidity is also explained by the intense precipitation over the years, which leads to the leaching of the exchangeable cations of the soil $\left(\mathrm{Ca}^{2+}, \mathrm{Mg}^{2+}\right.$, and $\left.\mathrm{K}^{+}\right)$, remaining in the soil only the cations that increase soil acidity $\left(\mathrm{H}^{+}\right.$and $\left.\mathrm{Al}^{3+}\right)$ (Theodoro et al.,2003).

The average values of CEC (T) as well as contents of $\mathrm{Ca}^{2+}, \mathrm{Mg}^{2+}, \mathrm{K}^{+}$and $\mathrm{V} \%$ contents in Entisol were medium to low (Ribeiro, Guimarães, \& Alvarez, 1999). However, when comparing to the native forest area, a slight increase in these values was observed, with the exception of $\mathrm{K}^{+}$, which presented low values in both systems.

Low levels of $\mathrm{K}^{+}, \mathrm{Ca}^{2+}, \mathrm{Mg}^{2+}$ in Entisol are expected due to the limitations of their chemical nature, since they are essentially quartzous soils lacking exchangeable minerals, which limits this nutrient reserve for plants (Carvalho et al., 2015). The results showed that the intensification of the management in this type of soil caused increases in the macronutrient levels, which indicated an improvement, although small, in the chemical attributes of the soil in relation to the soil of native forest.

Thus, the analyzed management systems presented more stable characteristics in relation to the native vegetation area, with respect to soil chemical attributes, except for potassium, to all other characteristics analyzed in the $0-10 \mathrm{~cm}$ depth. Therefore, although both systems presented very low CEC values $(<50 \%)$, which characterizes them as dystrophic, in Entisol, it is common to find lower buffer capacity, both for $\mathrm{pH}$ and for P-available, which can be compared to clayey or highly clayey soils with a higher buffer capacity and therefore require higher amounts of limestone for soil correction (Novais, Smyth, \& Nunes, 2007).

The values of CEC (T) and V\% for the management systems in Ultisol were all considered high, classifying the soil of these areas as Eutrophic (> 50\%); the two variables have a correlation of 0.60 , indicating that they are positively correlated.

The management system 3 and 5 in Ultisol presented the highest CEC values (17.25 and 15.38, respectively). In the case of system 5, this can be associated to soil correction and fertilization, while the area of system 3 (part of this area is located on a floodplain) has been in disuse for some years. However, because it has been used for subsequent years, it has a nutrient reserve that has accumulated over time. Moraes et al., (2008) observed that pasture areas abandoned in floodplains had higher $\mathrm{Ca}^{2+}, \mathrm{Mg}^{2+}, \mathrm{K}^{+}$and $\mathrm{pH}$ and therefore lower $\mathrm{Al}^{3+}$ values when compared to planted forests.

Table 5 shows the chemical composition of the soil in the depth of $10-20 \mathrm{~cm}$. The values of $\mathrm{pH}$ and aluminum saturation, which refers to soil acidity and aluminum toxicity, showed that the management systems presented $\mathrm{pH}$ values ranging from 4.74 to 5.78. The $\mathrm{pH}$ values showed that in Ultisol, the management systems had a slight acidity in the systems 3 and 4 , however the other systems had values close to the ideal for cultivation, ranging from 6.0 to 6.5 (Ronquim, 2010). However, the systems within Entisol had lower pH values (3.21 to 3.97), indicating high soil acidity. 
Table 5. Soil $\mathrm{pH}\left(\mathrm{CaCl}_{2}\right)$, phosphorus $\left(\mathrm{mg} \mathrm{dm}^{-3}\right)$, potassium $\left(\mathrm{K}^{+}\right)$, calcium $\left(\mathrm{Ca}^{2+}\right)$, magnesium $\left(\mathrm{Mg}^{2+}\right)$, base Saturation $(\mathrm{V} \%)$, aluminum Saturation, CEC (T) of Ultisol and Entisol quartzipsamment, in the depth of 10-20 cm in the different management systems.

\begin{tabular}{|c|c|c|c|c|c|c|c|}
\hline \multirow{2}{*}{ Soil } & \multicolumn{5}{|c|}{ Management } & \multirow{2}{*}{ Average } & \multirow{2}{*}{$\begin{array}{c}\text { CV } \\
\%\end{array}$} \\
\hline & 1 & 2 & 3 & 4 & 5 & & \\
\hline & \multicolumn{7}{|c|}{$\mathrm{pH}\left(\mathrm{CaCl}_{2}\right)$} \\
\hline Ultisol & $5.47 \mathrm{aB}$ & $5.78 \mathrm{aA}$ & $4.96 \mathrm{aC}$ & $4.74 \mathrm{aC}$ & $5.76 \mathrm{aA}$ & 5.34 & \multirow{2}{*}{4.5} \\
\hline Entisol & $3.61 \mathrm{bBC}$ & $3.5 \mathrm{bC}$ & $3.97 \mathrm{bA}$ & $3.21 \mathrm{bD}$ & $3.81 \mathrm{bAB}$ & 3.62 & \\
\hline \multirow[t]{2}{*}{ Average } & 4.54 & 4.64 & 4.47 & 3.97 & 4.79 & & \\
\hline & \multicolumn{7}{|c|}{$\mathrm{P}\left(\mathrm{mg} \mathrm{dm}^{-3}\right)$} \\
\hline Ultisol & $2.98 \mathrm{aA}$ & $3.11 \mathrm{aA}$ & $2.44 \mathrm{aA}$ & $2.50 \mathrm{aA}$ & $2.45 \mathrm{bA}$ & 2.7 & \multirow{2}{*}{21.2} \\
\hline Entisol & $2.74 \mathrm{aB}$ & $3.23 \mathrm{aAB}$ & $2.81 \mathrm{aB}$ & $2.56 \mathrm{aB}$ & $3.7 \mathrm{aA}$ & 3.01 & \\
\hline Average & 2.86 & 3.17 & 2.62 & 2.53 & 3.07 & & \\
\hline & \multicolumn{7}{|c|}{$\mathrm{K}^{+}\left(\mathrm{cmol}_{\mathrm{c}} \mathrm{dm}^{-3}\right)$} \\
\hline Ultisol & $0.05 \mathrm{aA}$ & $0.05 \mathrm{aA}$ & $0.02 \mathrm{aB}$ & $0.04 \mathrm{aA}$ & $0.04 \mathrm{aAB}$ & 0.04 & \multirow{3}{*}{50.9} \\
\hline Entisol & $0.002 \mathrm{bA}$ & $0.002 \mathrm{bA}$ & $0.003 \mathrm{bA}$ & $0.003 \mathrm{bA}$ & $0.004 \mathrm{bA}$ & 0.002 & \\
\hline Average & 0.027 & 0.023 & 0.013 & 0.021 & 0.021 & & \\
\hline \multicolumn{8}{|c|}{$\mathrm{Ca}^{2+}\left(\mathrm{cmol}_{\mathrm{c}} \mathrm{dm}^{-3}\right)$} \\
\hline Ultisol & $5.43 \mathrm{aB}$ & $4.56 \mathrm{aB}$ & $9.22 \mathrm{aA}$ & $5.96 \mathrm{aB}$ & $5.50 \mathrm{aB}$ & 6.13 & \multirow{3}{*}{40.7} \\
\hline Entisol & $0.04 \mathrm{bA}$ & $0.06 \mathrm{bA}$ & $0.09 \mathrm{bA}$ & $0.03 \mathrm{bA}$ & $0.19 \mathrm{bA}$ & 0.08 & \\
\hline Average & 2.74 & 2.31 & 4.65 & 3 & 2.84 & & \\
\hline \multicolumn{8}{|c|}{$\mathrm{Mg}^{2+}\left(\mathrm{cmol}_{\mathrm{c}} \mathrm{dm}^{-3}\right)$} \\
\hline Ultisol & $1.76 \mathrm{aB}$ & $3.10 \mathrm{aA}$ & $2.31 \mathrm{aB}$ & $1.78 \mathrm{aB}$ & $3.49 \mathrm{aA}$ & 2.49 & \multirow{2}{*}{42.4} \\
\hline Entisol & $0.14 \mathrm{bA}$ & $0.08 \mathrm{bA}$ & $0.21 \mathrm{bA}$ & $0.05 \mathrm{bA}$ & $0.17 \mathrm{bA}$ & 0.13 & \\
\hline \multirow[t]{2}{*}{ Average } & 0.95 & 1.59 & 1.26 & 0.91 & 1.83 & & \\
\hline & & & & $J(\%)$ & & & \multirow{4}{*}{9.9} \\
\hline Ultisol & 80.54 & 79.38 & 84.44 & 73.59 & 77.99 & $79.19 \mathrm{a}$ & \\
\hline Entisol & 7.24 & 3.86 & 16.67 & 2.6 & 8.44 & $7.76 \mathrm{~b}$ & \\
\hline Average & $43.89 \mathrm{~b}$ & $41.62 \mathrm{bc}$ & $50.55 \mathrm{a}$ & $38.10 \mathrm{c}$ & $43.21 \mathrm{~b}$ & & \\
\hline \multicolumn{8}{|c|}{$\mathrm{m} \%$} \\
\hline Ultisol & $1.3 \mathrm{aA}$ & $0 \mathrm{aA}$ & $2.23 \mathrm{aA}$ & $0 \mathrm{aA}$ & $0.5 \mathrm{aA}$ & 0.81 & \multirow{2}{*}{36.7} \\
\hline Entisol & $26.40 \mathrm{bBC}$ & $31.35 \mathrm{bB}$ & $17.93 \mathrm{bD}$ & $41.31 \mathrm{bA}$ & $22.64 b C D$ & 27.93 & \\
\hline Average & 13.85 & 15.67 & 10.09 & 20.65 & 11.57 & & \\
\hline \multicolumn{8}{|c|}{$\operatorname{CEC}\left(\mathrm{cmol}_{\mathrm{c}} \mathrm{dm}^{-3}\right)$} \\
\hline Ultisol & $9.00 \mathrm{aC}$ & $9.58 \mathrm{aBC}$ & $13.55 \mathrm{aA}$ & $10.51 \mathrm{aBC}$ & $11.57 \mathrm{aAB}$ & 10.84 & \multirow{2}{*}{22.3} \\
\hline Entisol & $2.63 \mathrm{bAB}$ & $3.75 \mathrm{bAB}$ & $1.94 \mathrm{bB}$ & $3.44 \mathrm{bAB}$ & $4.49 \mathrm{bA}$ & 3.25 & \\
\hline Average & 5.82 & 6.67 & 7.74 & 6.98 & 8.03 & & \\
\hline
\end{tabular}

Note. Lowercase letters compare columns. Capital letters compare rows. The averages followed by the same letter did not differ statistically from each other. The Tukey test was applied at 5\% probability level. $* 1$ - silvopasture with $30 \%$ shading, 2 - silvopasture with $60 \%$ shading, 3 - secondary forest, 4 - native forest, 5 - pasture with conventional management.Source: Authors.

In both soils (Table 5), system 4 (native forest) presented lower pH value (4.74) because in this system, there was no soil acidity correction or fertilization. The highest values were found in the management systems 2 and 5 (5.78 and 5.76 , respectively) in Ultisol and in the management system 3 (3.97) in Entisol. 
The higher $\mathrm{pH}$ values of Ultisol are related to the fact that both systems were managed for liming and fertilization, thus raising the $\mathrm{pH}$ values and soil CEC. In addition, it was possible to observe a positive correlation (0.77) between $\mathrm{pH}$ and organic matter, which may be related to negative soil OM loads that are dependent on soil pH (Monte Braga, 2010).

As for Entisol, the area that presented the highest $\mathrm{pH}$ value was the area of managed pasture (management system 5) that has been used over the years, and still presented $\mathrm{pH}$ values that are considered low. The area was managed for fertilization, but there was no soil correction, and because it is a soil with low soil colloid, it has a low buffering capacity, not retaining cations through fertilization, thus occurring the phenomenon known as leaching, a process that impoverishes the soil. This is also influenced by low CEC and SOM since the soil carbon stocks are intrinsically related to soil texture, and that there is an evident tendency of the increase of the carbon stock with the increase in clay content (Frazão et al., 2010).

Unlike the other attributes, for $\mathrm{V} \%$ there was no interaction between the factors, showing that factor 1 is independent of factor 2 in this attribute. However, factors 1 and 2 are statistically different, and the management system 3 presented the highest mean (84.44), differing statistically from the others, but not only this attribute, since in spite of having average values that can be considered very good in Ultisol, the $\mathrm{pH}$ values for system 3 are acidic, while the values of $\mathrm{K}^{+}$and $\mathrm{P}$ are the lowest.

These values of low $\mathrm{pH}$ and high $\mathrm{V} \%$ may also be related to the fact that the areas were previously used as pasture and are now in a state of abandonment. Although they are not being fertilized, there is a reserve of nutrients in the solution. GamaRodrigues et al. (2008), when evaluating the soil characteristics in different types of vegetation cover, also found $\mathrm{pH}$ values that indicated the high acidity of abandoned areas.

The values of $\mathrm{V} \%$ and $\mathrm{m} \%$ for the management systems in Ultisol correlated negatively (-0.46). As the values of $\mathrm{V} \%$ increased, the values of $\mathrm{m} \%$ decreased; this is expected since $\mathrm{m} \%$ is the percentage of soil loads that are occupied by exchangeable aluminum, thus expressing the level of aluminum toxicity in the soil and the saturation of bases expresses precisely the sum of cations in the exchangeable form in the soil solution, thus, the high values of base saturation indicate that the soil colloids are occupied by these exchangeable cations, and not by aluminum.

The values of $\mathrm{m} \%$ for management systems 1, 2, and 4 in Entisol were considered high (26, 41, and 31\%, respectively), while systems 3 and 5 presented values that are considered average (17.9-22.4\%) (Raij et al., 1986).

This shows that although areas 1,2, and 4 (silvopasture 30\%, silvopasture $60 \%$, and pasture, respectively) are managed with high values, which is detrimental to the development of the crops that were implanted there, without a prior correction of the soil that is adequate to the adopted management, it can cause soils to rapidly lose fertility due to acidification, mobilization of toxic elements $\left(\mathrm{Al}^{3+}, \mathrm{Fe}^{2+}\right.$, and $\mathrm{Mn}$ ), immobilization of nutrients and mineralization of soil organic matter (Theodoro et al., 2003).

The values found corroborate with Carvalho et al. (2015), who studied different management systems in Entisol quartzipsamment $\mathrm{s}$ and found high values of $\mathrm{m} \%$ and low $\mathrm{V} \%$ for pasture areas of conventional use, while for native forest and integrated system, found similar values compared to the present study. This shows that the average values found in Entisol are more related to the mineralogical deficiency of the soil and the treatments applied to it than to the adopted management system.

Soil $\mathrm{pH}$ and $\mathrm{Al}^{3+}$, responsible for the acidity found in the systems in each soil, showed that in this depth $(20-40 \mathrm{~cm})$ the lowest averages found in both soils were for the native forest areas (Table 6). This indicates a loss of exchangeable cations $\left(\mathrm{Ca}^{2+}\right.$, $\mathrm{Mg}^{2+}$, and $\mathrm{K}^{+}$) as the depth analyzed increases. A substitution of these cations in the colloid of the soil by aluminum and/or hydrogen occurs, which in turn increases the soil acidity.

This acidity is easily understood because in this system, which is used as a reference for the others, no type of treatment has been carried out to correct this acidity and to improve soil fertility.

Contents of $\mathrm{Mg}^{2+}$ and $\mathrm{K}^{+}$varied very little among the systems within the same soil type. System 2 in Ultisol obtained the highest average value of $\mathrm{Mg}^{2+}\left(2.97 \mathrm{cmol}_{\mathrm{c}} \mathrm{dm}^{-3}\right)$, which may be associated with higher litter load in this area, and therefore, 
greater increase of soil nutrient cycling. Bahamonde et al. (2012) reported that forest thinning to compose integrated systems could reduce nutrient recycling by 30 to $35 \%$.

Regarding V \%, the highest values of base saturation found in management area $2(81.15 \%)$, has a positive correlation with soil CEC (0.54), indicating that the two variables increased in parallel. However, V \% values decreased as the depth increased. The trees absorb nutrients from the deeper layers and transfer to superficial layers, providing an increase in the nutrient supply via litter, as well as improving the soil micro-flora, which contributes to accelerate the nutrient cycling (Silveira et al., 2007; Radomski, \& Ribaski, 2012).

The values of $\mathrm{m} \%$ in the management systems in Ultisol did not statistically differ, with a mean of 1.88 . However, for the management systems in Entisol quartzipsamment, the average values were high for the native forest area and for the silvopasture system with $60 \%$ shading.

High values were expected, since this variable had negative correlation with V \% (-0.76) and positive correlation with $\mathrm{Al}^{3+}(0.96)$ and $\mathrm{H}+\mathrm{Al}^{3+}(0.43)$. As the soil base saturation decreased, saturation was increased by aluminum; this is evident in the positive correlation with the exchangeable aluminum.

Along the soil profile, the average values of the exchangeable cations decreased, so the exchangeable aluminum takes the place of these cations on the surface of the soil colloids (Ronquim, 2010). Management systems that have higher base immobilization in their biomass present higher values of $\mathrm{Al}^{3+}$ and $\mathrm{H}+\mathrm{Al}^{3+}$, and this in turn directly influences the saturation of the soil (Freitas et al., 2013).

Management system 2, which is an area with $60 \%$ shading, with a lesser extent of the original forest, maintained a high average $\mathrm{m} \%(42.75 \%)$. This can be attributed to the fact that having a lower content of exchangeable cations and therefore a low CEC, the nutrients are less retained, increasing the potential acidity of the soil. Thus, it should be handled with more rigorous criteria than soils with higher clay contents, in order to reach their maximum productive potential, without loss of soil quality (Carneiro et al., 2009). 
Table 6. Soil $\mathrm{pH}\left(\mathrm{CaCl}_{2}\right)$, Aluminum $\left(\mathrm{Al}^{3+}\right)$, Calcium $\left(\mathrm{Ca}^{2+}\right)$, Magnesium $\left(\mathrm{Mg}^{2+}\right)$, Potassium $\left(\mathrm{K}^{+}\right)$, and CEC (T), base saturation (V \%), and aluminum saturation (m \%) of Ultisol and Entisol quartzipsamment, in the depth of 20-40 $\mathrm{cm}$ in the different management systems.

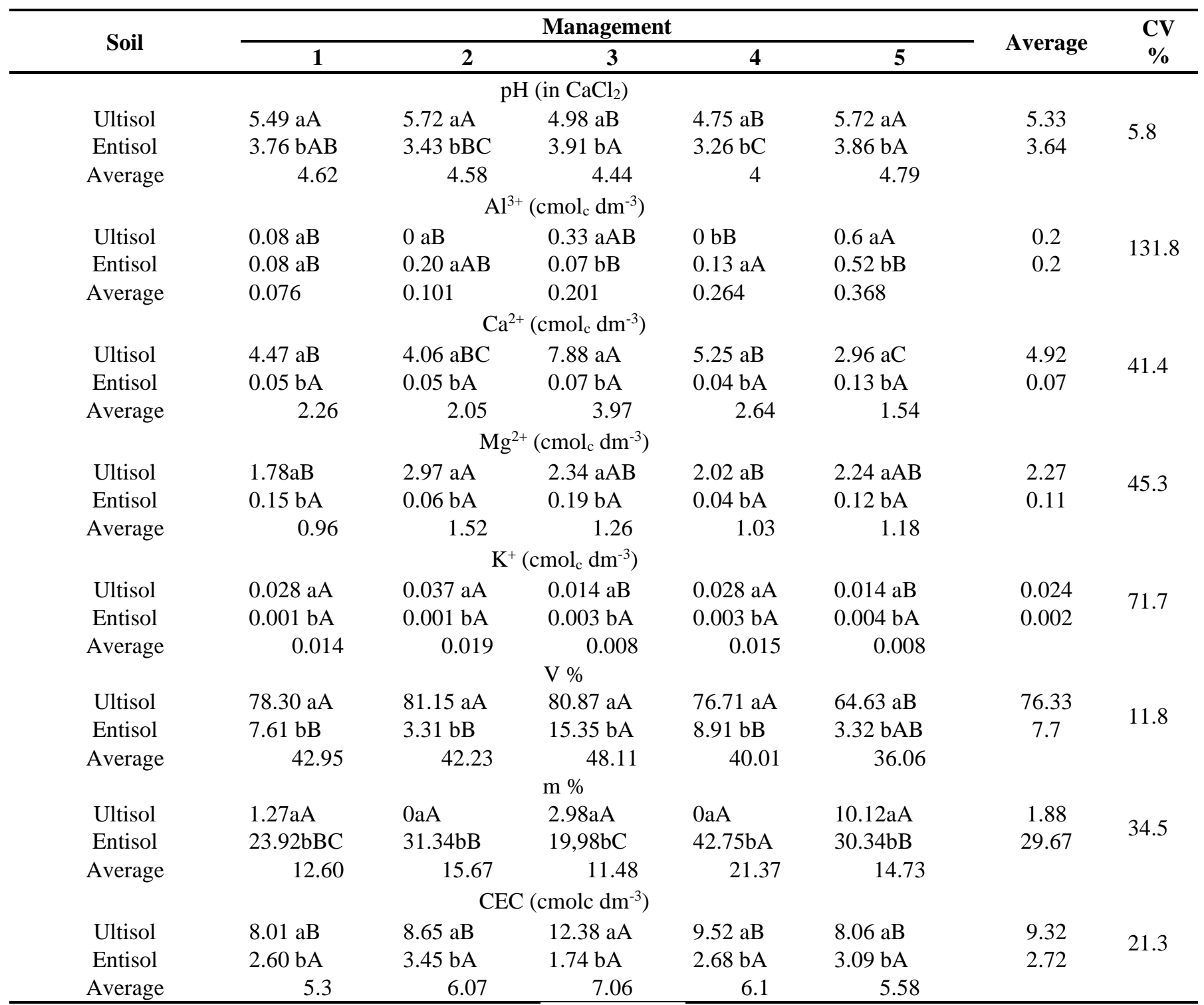

Note. Lowercase letters compare columns. Capital letters compare rows. The averages followed by the same letter did not differ statistically from each other. The Tukey test was applied at 5\% probability level. *1 - silvopasture with $30 \%$ shading, 2 - silvopasture with $60 \%$ shading, 3 - secondary forest, 4 - native forest, 5 - pasture with conventional management. Source: Authors.

\section{Conclusion}

The chemical components in both areas, in Entisol the analyzed attributes did not have great dissimilarities, demonstrating that regardless the system, the lack of nutrients is notorious in this type of soil, which is a problem that can be overcome by adopting practices aiming at correcting soil acidity and soil nutrient deficiency.

In Ultisol the pasture area and silvopasture of $60 \%$ shading, stood out in relation to chemical attributes of the soil, the average values found in the areas indicate that when well-managed, regardless of the adopted system, the chemical quality of the soil does not is affected. But it should be noted that the Silvipastoril System adds more sustainability characteristics to the management. 


\section{References}

Araújo, R. A., Costa, R. B., Felfili, J. M., Gonçalvez, I. K., Sousa, R. A. T. M., \& Dorval, A. (2009). Florística e estrutura de The chemical components in both areas, in Entisol the analyzed attributes did not have great dissimilarities, demonstrating that regardless the system, the lack of nutrients is notorious in this type of soil, which is a problem that can be overcome by adopting practices aiming at correcting soil acidity and soil nutrient deficiency.

In Ultisol the pasture area and silvopasture of $60 \%$ shading, stood out in relation to chemical attributes of the soil, the average values found in the areas indicate that when well-managed, regardless of the adopted system, the chemical quality of the soil does not is affected. But it should be noted that the Silvipastoril System adds more sustainability characteristics to the management. fragmento florestal em área de transição na Amazônia Mato-grossense no município de Sinop. Acta amazônica, 39, 865-878. 10.1590/S0044-59672009000400015.

Alves, S. M. de F., Queiroz, D. M. de, Alcântara, G. R. de, \& Reis, E. F. dos. (2014). Variabilidade espacial de atributos físico-químicos do solo usando técnicas de análise de componentes principais e geoestatística. Bioscience Journal, 30. http://www.seer.ufu.br/index.php/biosciencejournal/article/view/14069.

Bockheim, J. G., Gennadiyev, A. N., Hartemink, A. E., \& Brevik, E. C. (2014). Fatores formadores de solo e taxonomia do solo. Geoderma , 226 , $231-237$.

Bahamonde, H. A., Peri, P. L., Alvarez, R., Barneix, A., Moretto, A., \& Pastur, G. M. (2012). Litter decomposition and nutrients dynamics in Nothofagus Antarctica forests under silvopastoral use in Southern Patagonia. Agroforestry Systems, 84, 345-360. 10.1007/s10457-012-9479-7

Benavides, R., Douglas, G. B., \& Osoro, K. (2009). Silvopastoralism in New Zealand: review of effects of evergreen and deciduous trees on pasture dynamics. Agroforestry System, 76, 327-350. 10.1007/s10457-008-9186-6.

Bono, J. A. M., Macedo, M. C. M., \& Tormenta, C. A. (2013). Qualidade física do solo em um Latossolo vermelho da região sudoeste dos cerrados sob diferentes sistemas de uso e manejo. Revista Brasileira de Ciência do Solo, 37, 743-753. 10.1590/S0100-06832013000300021

Carneiro, M. A. C., Souza, E. D., Reis, E. F., Pereira, H. S., \& Azevedo, W. R. (2009). Atributos físicos, químicos e biológicos de solo de cerrado sob diferentes sistemas de uso e manejo. Revista Brasileira de Ciência do Solo, Viçosa-MG, 33(1), 147-157.

Carvalho, R. P., Omar, D., Davide, A. D., \& Souza, F. R. (2015). Atributos físicos e químicos de um Neossolo Quartzarênico sob diferentes sistemas de uso e manejo. Revista Caatinga, 28, 148-159. https://www.redalyc.org/articulo.oa?id=237138297016.

Cordeiro, F. C., Pereira, M. G., Anjos, L. H. C., Zonta, E., Loss, A., \& Staffanto, J. B. (2010). Atributos edáficos em pastagens da região noroeste do estado do Rio de Janeiro. Comunicata Scientiae, 1, 106.

Dubreuil, V., Fante, K. P., Planchon, O., \& Neto, J. L. S. A. (2018). Os tipos de climas anuais no Brasil: uma aplicação da classificação de Köppen de 1961 a 2015. Confins. Revue franco-brésilienne de géographie/Revista franco-brasilera de geografia, (37). https://doi.org/10.4000/confins.15738.

Frazão, L. A., Santana, I. K. S., Campos, D. V. B., Feigl, B. J., \& Cerri, C. C. (2010). Estoques de carbono e nitrogênio e fração leve da matéria orgânica em Neossolo Quartzarênico sob uso agrícola. Pesquisa Agropecuária Brasileira, 45, 1198-1204. 10.1590/S0100-204X2010001000020

Freitas, I. C. D., Santos, F. C. V. D., Custódio Filho, R. D. O., Correchel, V., \& Silva, R. B. D. (2013). Agroecossistemas de produção familiar da Amazônia e seus impactos nos atributos do solo. Revista Brasileira de Engenharia Agrícola e Ambiental, 17, 1310-1317.

Gama-Rodrigues, E. F., Barros, N. F., Viana, A. P., \& Santos, G. A. (2008). Alterações na biomassa e na atividade microbiana da serapilheira e do solo, em decorrência da substituição de cobertura florestal nativa por plantações de eucalipto, em diferentes sítios da região sudeste do Brasil. Revista Brasileira de Ciência do Solo, 32, 1489-1499. 10.1590/S0100-06832008000400013

Godinho, O. T., Caldeira, M. V. W., Caliman, J. P., Prezotti, L. C., Watzlawick, L. F., Azevedo, H. C. A., \& Rocha, J. H. T. (2014). Quantificação de biomassa e nutrientes na serapilheira acumulada em trecho de Floresta Estacional Semidecidual Submontana, ES. Cerne, 20, 11-20. 10.1590/S0104-77602014000100002

Guedes, M. C., Andrade, C. A., Poggiani, F., \& Mattiazzo, M. E. (2006). Propriedades químicas do solo e nutrição do eucalipto em função da aplicação de lodo de esgoto. Revista Brasileira de Ciência do Solo, 30, 267- 280. 10.1590/S0100-06832006000200008.

Loss, A.,Pereira, M. G., Schultz, N., Anjos, L. H. C., \& Silva, E. M. R. (2009). Atributos químicos e físicos de um Argissolo Vermelho-Amarelo em sistema integrado de produção agroecológica. Pesquisa Agropecuária Brasileira, 44(1), 68-75.

Lyra, W. S., Silva, E. C., Araújo, M. C. U., Fragoso, W. D., \& Veras, G. (2010). Classificação periódica: um exemplo didático para ensinar análise de componentes principais. Química Nova, 33, 1594-1597. 10.1590/S0100-40422010000700030

Mancilla-Leytón, J. M., Sánchez-Lineros, V., \& Vicente, A. M. (2013). Influence of grazing on the decomposition of Pinus pinea L. needles in a silvopastoral system in Doñana, Spain. Plant and Soil, 373, 173-181. 10.1007/s11104-013-1788-8

MMA (Ministério do Meio Ambiente). (2003). Ibama conclui mapeamento dos biomas brasileiros. http://www.mma.gov.br Acess in: 16/09/2018.

Monte Braga, G. N. (2010). A acidez do solo - ativa e potencial- Na sala com gismonti assuntos sobre agronomia. https://agronomiacomgismonti.blogspot.com

Novais, R. F., Smyth, T. J., \& Nunes, F. N. (2007). Fósforo. In: Novais, R. F., Alvarez, V. H., Barros, N. F., Fontes, R. L. F., Cantarutti, R. B., \& Neves, J. C. L. (Ed.). Fertilidade do solo. Viçosa: Sociedade Brasileira de Ciência do Solo :550p.

Oliveira, T. P., Ensinas, S. C., Barbosa, G. F., Nanzer, M. C., \& Barreta, P. G. V. (-2017). Atributos químicos de um Neossolo Quartzarênico de cerrado sob diferentes sistemas de uso e manejo. Revista de Agricultura Neotropical, Cassilândia-MS, v. 4, Suplemento 1, p. 72-78. ISSN 2358-6303. 10.32404 /rean.v4i5.2182.

Moraes, L. F. D., Campello, E. F. C., Pereira, M. G., \& Loss, A. (2008). Características do solo na restauração de áreas degradadas na Reserva Biológica de Poço das Antas, RJ. Ciência Florestal, 18, 193-206. 
Research, Society and Development, v. 10, n. 7, e36210716045, 2021

(CC BY 4.0) | ISSN 2525-3409 | DOI: http://dx.doi.org/10.33448/rsd-v10i7.16045

Radomski, M., \& Ribaski, J. (2012). Fertilidade do solo e produtividade da pastagem em sistema silvipastoril com Grevillea robusta. Pesquisa Florestal Brasileira, 32, 53-61. 10.4336/2012.pfb.32.69.53

Raij, B. V., Cantarella, H., Quagio, J. A., \& Furlani, A. M. C. (1986). Recomendações de adubação e calagem para o Estado de São Paulo. (2ª .ed.): Instituto

Agronômico (IAC. Boletim Técnico, 100)

Rencher, A. C. (2002). Methods of Multivariate Analysis, Second Edition. [s.1: s.n.], 37, 727.

Ribeiro, A. C., Guimarães, P. T. G., \& Alvarez, V. V. H. (1999). Recomendações para o uso de corretivos e fertilizantes em Minas Gerais - 5ª Aproximação. Viçosa: Comissão de Fertilidade do Solo do Estado de Minas Gerais, 360p.

Rocha Junior, P. R., Silva, V. M., \& Guimarães, G. P. (2013). Degradação de pastagens brasileiras e práticas de recuperação. Enciclopédia Biosfera, 9, 952968.

Ronquim, C. C. (2010). Conceitos de fertilidade do solo e manejo adequado para regiões tropicais. Boletim de Pesquisa e Desenvolvimento. Embrapa Monitoramento por Satélite, 8, 30.

Santos, H. G., Jacomine, P. K. T., Dos Anjos, L. H. C., De Oliveira, V. A., Lumbreras, J. F., Coelho, M. R., \& Cunha, T. J. F. (2018). Sistema brasileiro de classificação de solos. Brasília, DF: Embrapa, 2018.

Silveira, N. S., Pereira, M. G., Polidoro, J. C., Tavares, S. R. L., \& Mello, R. B. (2007). Aporte de nutrientes e biomassa via serapilheira em sistemas agroflorestais em Paraty. Ciência Florestal, 17, 129-136.

Theodoro, V. D., Alvarenga, M. I. N., Guimarães, R. J., \& Souza, C. A. S. (2003). Alterações químicas em solo submetido a diferentes formas de manejo do cafeeiro. Revista Brasileira de Ciência do Solo, 27, 1039-1047.

Wall, A. J. (2006). The effect of poplar stand density on hill country pastures. 314p. 